\title{
THE COMPARISON OF THE POROSITY FORMATION IN DIFFERENT CASTED SECONDARY ALUMINIUM ALLOY
}

\begin{abstract}
The porosity formation in secondary aluminium cast alloys are one of the main aspect which can affect the final properties of casts. Whereas these materials are especially used for production the automotive casts such as engine blocks, cylinder head, chassis components and so on, it is need the production of the casts without deleterious defects. The contributions deals with comparison of the porosity formation in secondary AlSi9Cu3 cast alloy when different moulds (the metallic mould and sand mould) for casting were used. The material was gravity casted in the both mould. The differences in microstructure and porosity formation were studied by using light metallography microscopy and image analyser software. The evolution shows that the experimental material casted into the metallic mould had about $98.78 \%$ smaller porosity size in comparison to the material casted into the sand mould, therefore it showed better properties.
\end{abstract}

Keywords: secondary aluminium alloy, porosity, sand mould, metallic mould.

\section{Introduction}

Porosity occurs in cast aluminium-silicon alloys during solidification due to the negative pressure generated by solidification contraction and the pressure development by evolution of dissolved hydrogen from the growing solid into the adjacent liquid (ZuO Y. 2011). Porosity can be also classified as a leading cause of reducing mechanical properties, particularly fatigue resistance, as well as a loss of pressure stress and degradation of the surface appearance in cast parts (PALYGA L. 2016; ANSON J. P. 1999; GONZÁlEZ R. 2013; BOLIBRUCHOVÁ D. 2016).

Castings are produced in hundreds of compositions by all commercial casting processes, including green sand, dry sand, composite mould, plaster mould, investment casting, permanent mould, counter-gravity low-pressure casting, and pressure die casting.

Aluminium cast alloys can be divided into two groups: those most suitable for gravity casting by any process and those used in pressure die casting. Melting and casting lead to the formation of disturbing textures, such as casting defects and disturbances arisen by heat treatment. Lower cooling rate setting when casting into

\footnotetext{
${ }^{1}$ Ing., PhD., University of Žilina, Department of Materials Engineering, e-mail: lenka.kucharikova@fstroj.uniza.sk

2 prof., Ing., PhD., University of Žilina, Department of Materials Engineering, e-mail: eva.tillova@ fstroj.uniza.sk
} 
a sand mould (sand casting) results in a granular structure and lower values of material properties. Higher cooling rate setting when casting into a metallic mould (chill casting) results in a fine-grained structure and higher values of material properties. Reduced mechanical properties and reliability of aluminium cast alloys can be principally caused by the presence of defects and inhomogeneities (TILlOVÁ E. 2010; Rosso M. 2005; PUCHER P. 2011; ŤAVODOVÁ M. 2016). Based on the knowledge that dynamic engineering world continues to exert enormous demands for durable and cost effective materials (NOVÝ F. 2016) the casts form AlSi9Cu3 cast alloy were studied. This type of material is used for automotive casts and for example cylinder heads have critical requirements onto microstructure and properties in areas like the combustion face; the automotive parts that exhibit high complexity, such as intake manifolds, and they may have very low properties thanks casting, solidification, and heat treatments, etc. process (MAJOR J.F. 2002).

The study was especially carried out to investigate the influence of usage different moulds during casting to porosity formation in $\mathrm{AlSi} 9 \mathrm{Cu} 3$ secondary cast alloy.

\section{Material and experimental procedures}

The experimental material is secondary cast AlSi9Cu3 alloy (prepared from recycled aluminium scrap) delivered from two companies - Uneko, spol.s.r.o. (sand casting - sand mould - Fig. 1a), and Confal a.s. (chill casting - metallic mould - Fig. 1b). The experimental materials were not modified or grain refined. The chemical composition of the two experimental materials was checked out using arc spark spectroscopy, and it is shown in Table 1.

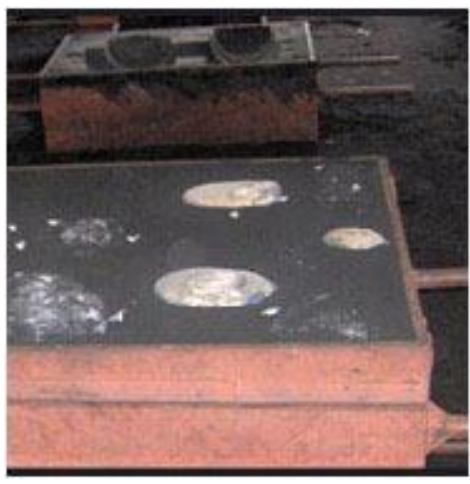

a) sand mould

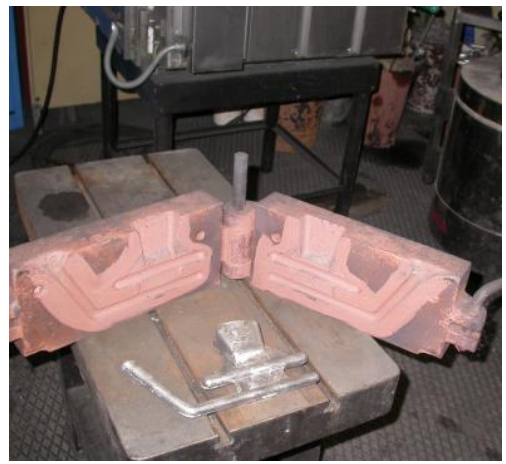

b) metallic mould

Fig. 1. Two different moulds for casting experimental material.

Source: own study 
The chemical compositions show, that these alloys have comparable amount of $\mathrm{Cu}, \mathrm{Mg}, \mathrm{Si}$ and $\mathrm{Fe}$; so the formation of microstructure features will be the same.

Table 1. Chemical composition of experimental materials in wt. \%

AlSi9Cu3 - sand casting - Uneko, spol.s.r.o.
\begin{tabular}{|l|l|l|l|l|l|l|l|l|l|l|}
\hline $\mathbf{S i}$ & $\mathbf{C u}$ & $\mathbf{M n}$ & $\mathbf{Z n}$ & $\mathbf{M g}$ & $\mathbf{F e}$ & $\mathbf{N i}$ & $\mathbf{T i}$ & $\mathbf{S n}$ & $\mathbf{P b}$ & $\mathbf{A l}$ \\
\hline 10.7 & 2.4 & 0.25 & 1.0 & 0.26 & 0.9 & 0.1 & 0.05 & 0.02 & 0.00 & remainder \\
\hline \\
AlSi9Cu3 - chill casting - Confal a.s. \\
\hline $\mathbf{S i}$ & $\mathbf{C u}$ & $\mathbf{M n}$ & $\mathbf{Z n}$ & $\mathbf{M g}$ & $\mathbf{F e}$ & $\mathbf{N i}$ & $\mathbf{T i}$ & $\mathbf{S n}$ & $\mathbf{P b}$ & $\mathbf{A l}$ \\
\hline 9.4 & 2.4 & 0.24 & 1.0 & 0.28 & 0.9 & 0.05 & 0.04 & 0.03 & 0.09 & remainder \\
\hline
\end{tabular}

Source: own study

The amount of $\mathrm{Fe}$ is higher, comparison with primary aluminium alloys, for both experimental materials, and is expected the effect of this element on formation of porosity (ŠVECOVÁ I. 2017). Lu in his work (LU L. 2005) reported the Otte's research into examining the effect of iron on porosity formation in AlSi9Cu3 alloy. Otte has found that the total level of porosity increased slightly with iron content and that a large region of interconnected "sponge-like" porosity formed at high iron contents (Lu L. 2005).

Mechanical properties were measured according to the following standards: STN EN ISO 6892-1:2010 and STN EN ISO 6506-1. The experimental tensile and hardness specimens for experimental procedure were made from the casting with turning and milling operations. Hardness measurement for secondary aluminium alloy was performed using a Brinell hardness (HBW) tester with a load of $62.5 \mathrm{Kp}, 2.5 \mathrm{~mm}$ diameter ball and a dwell time of $15 \mathrm{~s}$. The evaluated Brinell hardness reflects average values of at least six separate measurements. Tensile strength (UTS) was measured using ZDM 30 testing machine. The evaluated UTS and HBW reflect average values of at least six separate specimens.

Light microscopy was used to analyse the microstructure and porosity of the materials after tensile test. The main point was quantitative analysis of porosity in the specimens, which was carried out using a NEOPHOT 32 light microscope equipped with a computer running NIS Element 4.0 image analyser software (SKOČOVSKÝ P. 2000). The pore size (area) and amount (surface fraction) were detected on longitudinal and transverse sections of the specimens. The resulting value of the measured parameters reflect average values of at least twenty separate measurements on each used specimens for tensile test. The specimens for metallographic analysis 
were prepared by standard metallographic procedures (wet ground on $\mathrm{SiC}$ papers, DP polished with $3 \mu \mathrm{m}$ diamond pastes followed by Struers Op-S and etched for study under-an optical microscope by standard etcher Dix-Keller and $0.5 \% \mathrm{HF}$ ).

\section{Experimental results}

Alloy AlSi9Cu3 casted into a sand mould has a significantly smaller value of HBW and UTS than the same alloy casted into a metallic mould (Fig. 2). The tensile strength of the materials casted into a sand mould was $143 \mathrm{MPa}$, and that of the material casted into metallic moulds was $211 \mathrm{MPa}$.

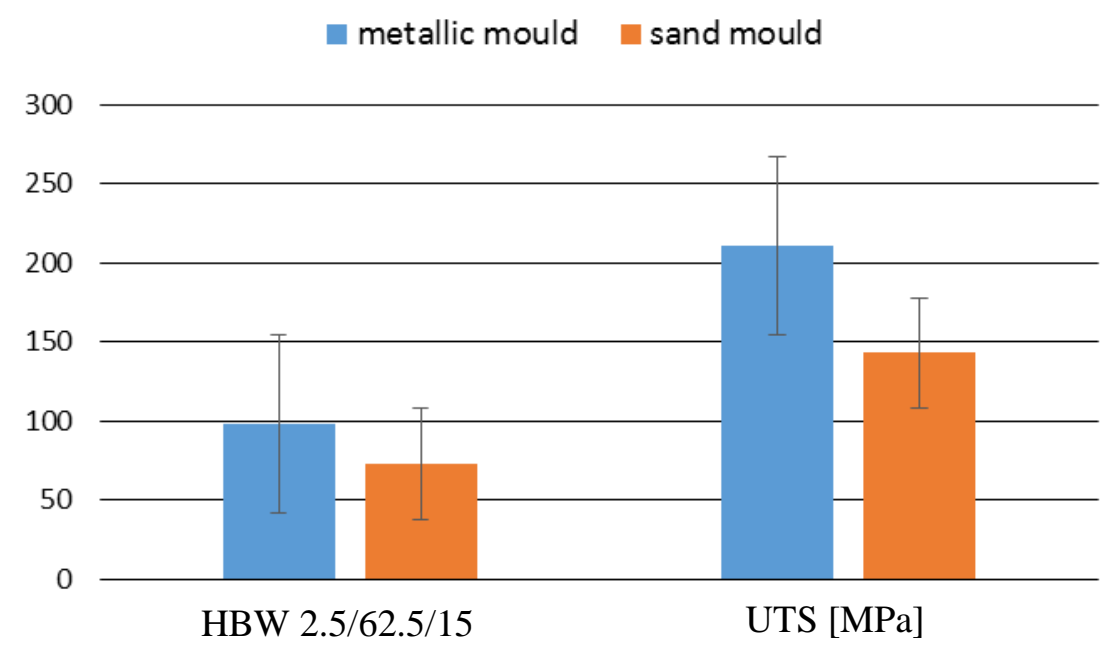

Fig. 2. Ultimate tensile strength of AlSi9Cu3 alloys casted into different moulds. Source: own study

The material casted into metallic moulds has about $32 \%$ higher tensile strength compared to the material casted into sand moulds. The Brinell hardness for the material casted into sand moulds was $73 \mathrm{HBW} 2.5 / 62.5 / 15$, and that for the material casted into metallic moulds was $98 \mathrm{HBW} 2.5 / 62.5 / 15$. The material casted into metallic moulds has higher Brinell hardness by about $25 \%$ compared to the material casted into sand moulds.

The metallography studies show that both experimental materials contain mostly solidification defects, especially shrinkage porosity (Fig. 2.3) (FINTOVÁ S. 2008). The material casted into the sand mould mostly has shrinkage porosity types: macroporosity, and microporosity in small volume (CAMPBELL J. 1994) (Fig. 2.3a). 
The material casted into a metallic mould has the following shrinkage porosity types: microporosity mostly, but in very small volumes, and were also identified macroporosity (CAMPBELL J. 1994) (Fig. 2.3b). Intermetallic phases, especially $\mathrm{Fe}$ rich intermetallic phases, are effective pore nucleation sites (MAHTA M. 2007, BANGYIKHAN K. 2005, YU J. 2016).

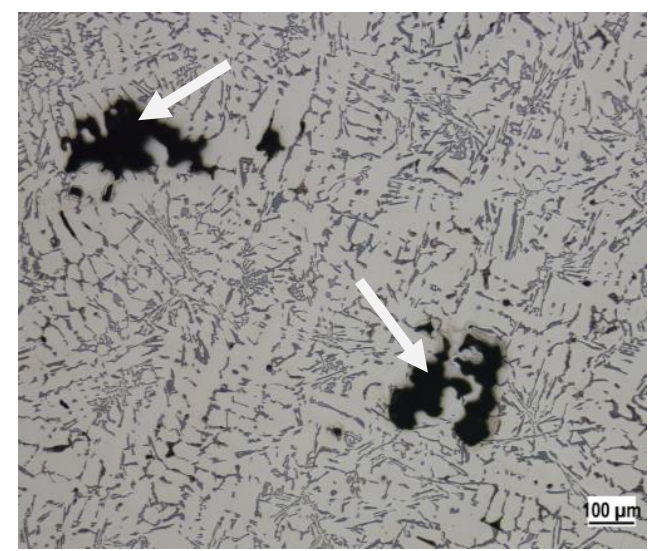

a) Sample casted into sand mould

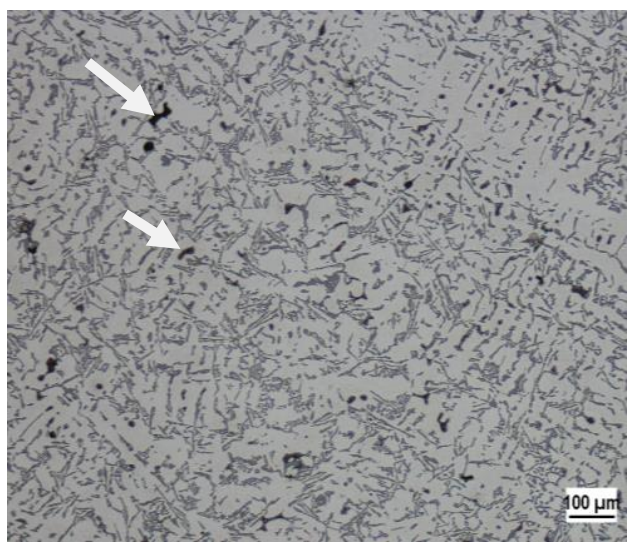

b) Sample casted into metallic mould

Fig. 3. Porosity in AlSi9Cu3 casted into different moulds.

Source: own study

Quantitative analysis of shrinkage porosity confirms that the material casted into a metallic mould has a very small average area of pores in comparison to the same material casted into a metallic mould (Fig. 4), because the material casted into the metallic mould has about $4680 \mu \mathrm{m}^{2}$ (transverse section) and $4923 \mu \mathrm{m}^{2}$ (longitudinal section) average area of pores, compared to $42301 \mu \mathrm{m}^{2}$ (transverse section) and 47309 $\mu \mathrm{m}^{2}$ (longitudinal section) in the material casted into the sand moulds, which is about $90 \%$ larger average area.

The difference between evaluated average pore area and average surface fraction on samples casted into metallic mould and samples casted into sand mould were great.

The samples casted into the sand mould have average surface fraction $3.85 \%$ and samples casted into metallic mould $0.625 \%$, which is about $83 \%$ lower amount of pores in microstructure of samples casted into the metallic mould.

Evaluation of average pores area shows that the material casted into the sand mould have larger pores $-42301 \mu \mathrm{m}^{2}$ while material casted into the metallic mould have average pores area $4680 \mu \mathrm{m}^{2}$, which is about $89 \%$ smaller size. 
average area of pores

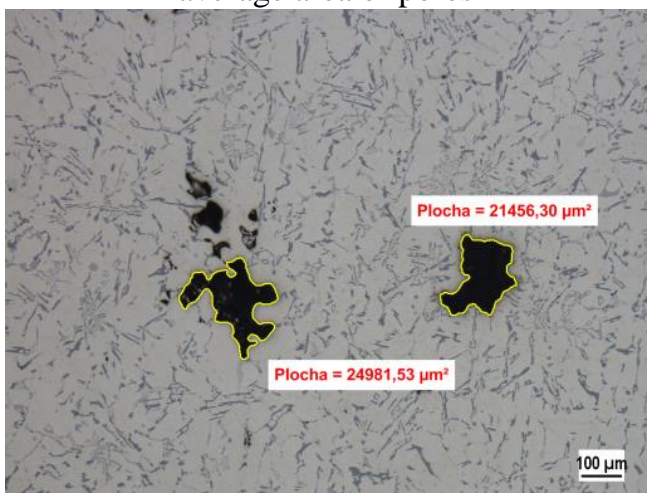

a) Sample casted into sand mould
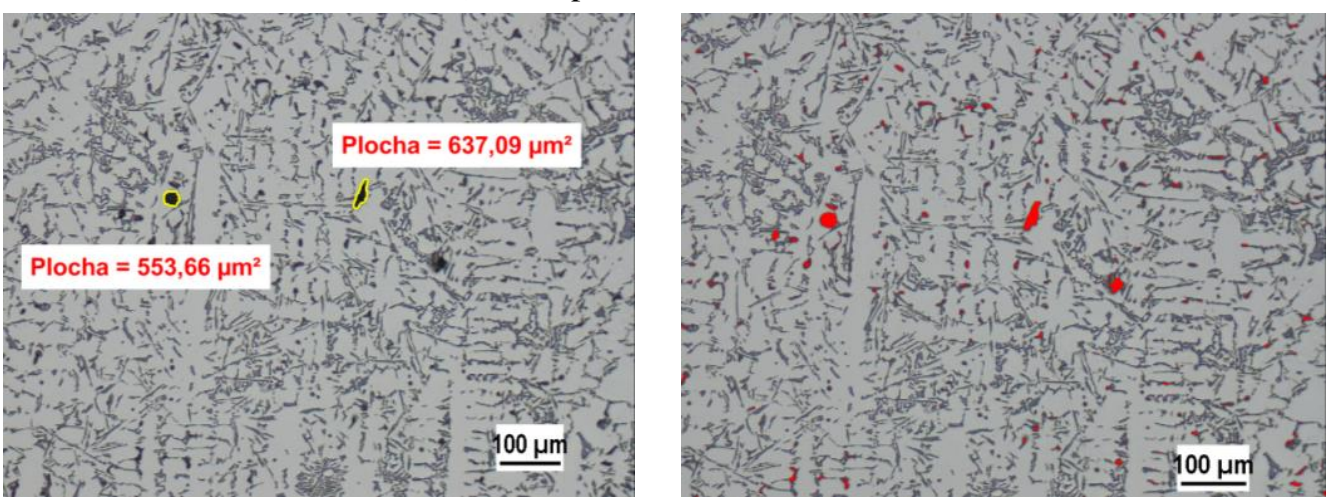

b) Sample casted into metallic mould

Fig. 4. Quantitative analysis of shrinkage porosity in AlSi9Cu3 cast alloy. Source: own study

These facts show that the material casted into a metallic mould would have better mechanical and fatigue properties, because of the size, amount and morphology of porosity.

\section{Conclusions}

The presented study has confirmed the differences in the production of aluminium castings using different casting moulds. Mechanical properties of the material casted into a sand mould were deteriorated. The material casted into a metallic mould has about 32\% higher tensile strength and about 25\% higher Brinell hardness, in comparison to the material casted into sand mould. 
The shrinkage porosity evolution in experimental materials shown the influence of different moulds on porosity creation. The material casted into a sand mould has a greater porosity size in comparison to the material casted into a metallic mould, which is probably associated with cooling rates of these materials.

\section{Acknowledgement}

This research has been supported by the Scientific Grant Agency of the Ministry of Education of the Slovak Republic VEGA 01/0533/15 and European Union project ITMS 26220220154.

\section{Bibliography}

1. Anson J. P., GRUZLESKI J. E. 1999. The Quantitative Discrimination between Shrinkage and Gas Microporosity in Cast Aluminum Alloys Using Spatial Data Analysis. Materials characterization, Vol. 43, pp. 319-335.

2. BANGYIKHAN K. 2005. Effects of Oxide film, Fe-rich phase, Porosity and their Interactions on Tensile Properties of Cast Al-Si-Mg Alloys. PhD thesis. School of Metallurgy and Materials, Faculty of Engineering, University of Birmingham, United Kingdom.

3. Bolibruchová D., RichtÁReCh L. 2016. Possibilities of using Al-Si-Mg alloys with higher Fe content for demanding castings. Manufacturing technology, Vol. 16, No. 2, pp. 317-323.

4. CAMPBell J., Harding R.A. 1994. Solidification Defects in Castings. TALAT Lecture 3207, EAA - European Aluminium Association.

5. Fintova S., Konstantova V., KoneČna R., Nicoletto G. 2008. Experimental study of porosity and fatigue behavior of cast Al-Si alloys. 17th International Metallurgical \& Materials Conference, Hradec nad Moravicí, TANGER Ostrava, CD-ROM (no. 54).

6. González R., González A., Talamantes-Silva J., Valtierra S., Mercado-Solís R.D., GARZA-MONTES-DE-OCA N.F., COLÁS R. 2013. Fatigue of an aluminium cast alloy used in the manufacture of automotive engine blocks. International Journal of Fatigue, Vol. 54, pp. 118-126.

7. LU L., DAHLE A.K. 2005. Iron-rich intermetallic phases and their role in casting defect formation in hypoeutectic Al-Si Alloys. Metallurgical and materials transactions A, Vol. 36A, pp. 819-835.

8. Mahta M., Emamy X.C., CAmpbell L. 2007. Overview of beta Al $l_{5} F e S i$ phase in Al-Si alloys. In: Materials Science Research Trends. Editor: Lawrence V. Olivante, Nova Science Publishers, pp. 1-16.

9. MAJOR J.F. 2002. Porosity Control and Fatigue Behavior in A356-T61 Aluminum Alloy. In: AFS Transactions, Vol. 97-94, pp. 901- 906. 
10. NovÝ F., Kopas P., BOKU゚VKa O., SAVIN A. 2016. Fatigue durability of ductile iron in very-high-cycle region. Manufacturing technology, Vol. 16, No. 2, pp. 406-409.

11. Palyga L., Stachowicz M., Granat K. 2016. Influence of High-presure-die-casting second stage parameter on structure of $\mathrm{AlSi} 9 \mathrm{Cu} 3(\mathrm{Fe})$ alloy. Manufacturing technology, Vol. 16, No. 2, pp. 410-416.

12. Pucher P., Böttcher H., Kaufmann H., AntreKowitsch H., Uggowitzer P.J. 2011. Mechanical properties and casting characteristics of the secondary aluminium alloy AlSi9Cu3(Fe) (A226). In: Supplemental Proceedings: Materials Fabrication, properties, characterization, and modelling. The mminerals, metals \& materials soviety, Vol. 2, pp. 237-244.

13. Rosso M. 2005. The influence of casting process on quality and performances on Al based automotive components. In: Proceeding of 13th International scientific conference on Achievements in mechanical and materials engineering, pp. 547-550. Poland, Gliwice.

14. SKoČOvskÝ P., BENKO P., VAŠKO A. 2000. Quantitative appreciation of structure and fracture surface of casting materials. In: Proccedings of Advanced manufacturing and repair technologies in vehicle industry, pp. 51-55 Zielona Góra - Łagów, Poland.

15. STN EN ISO 6892-1:2010 (42 0310). Metallic materials. Tensile testing. Part 1: Method of test at ambient temperature.

16. STN EN ISO 6506-1:2015 (42 0371). Metallic materials. Brinell hardness. Part 1: Test method.

17. ŠVecovÁ I., Tillová E., KuChariKovÁ L. 2017. Structural analysis of iron based intermetallic phases in secondary AlSi6Cu4 cast alloy. Production Engineering Archives (in press).

18. Tillová E., Hurtalová L., Chalupová M., Ďuriníková E. 2010. Quality control of secondary (recycled) Al-Si cast alloy. In: Toyotarity - Structure of control elements importance: monography. (Yurij V. Makovetsky, (Ed.)), pp. 48-63. Dnipropetrovsk.

19. ŤAvodová M., KALINCOVÁ D. 2016. Improving the Quality of Castings Using Thermovision. Manufacturing Technology, Vol. 16, No. 1, pp. 268-273.

20. YU J. 2016. Formation of Intermetallic Phases in Al-10Si-O.3Fe based Alloys. PhD thesis. December, Berlin, 134.

21. ZuO Y., Li H., XiA M., JiAng B., Scamans G.M., FAn Z. 2011. Refining grain structure and porosity of an aluminium alloy with intensive melt shearing. Scripta Materialia, Vol. 64, pp. 209-212. 